\title{
CAPACITY AND FORM OF MARRIAGE IN THE CONFLICT OF LAWS
}

I

\author{
BARS IMPOSED BY.PERSONAL IAW
}

The development of private international law seems to have this in common with the evolution of public international law, that it proceeds in a bewildering sort of zig-zag fashion: a settled proposition appears to be laid down and to obtain universal acceptance, upon which the world has no occasion for it for a decade or two, completely forgets it, and after a spell of other activities treats the settled rule as though it had never been, and ultimately works round to it again de novo. Long spells of maritime peace, such as that between 1865 and I904, made the world forget the laws of war at sea. In $186 \mathrm{I}$ Brook $v$. $B r o o k^{1}$ emphatically enunciates the paramountcy of the personal law in respect of capacity ${ }^{2}$ for marriage, and in 1907 the personal law is set on one side in Ogden $v$. Ogden. ${ }^{3}$

The infrequency of these cases involving persons and places of different national complexion has hitherto made it inevitable that there should be no strong catena of decisions-no abiding judicial consciousness of the proper rule. All the more important is it that the true principle should be made so clear by science that courts cannot be misled.

But it is not so easy to say what the principle is.

It is probable that this is just one of those cases in which any principle is better than uncertainty. Brook v. Brook, decided long ago by the very highest English tribunal (the House of Lords), and by four of the greatest names in British jurisprudence, seemed to have given a clear and certain rule. Of

\footnotetext{
${ }^{1}$ (186r) 9 H. L. Cas. I93.

2 "Capacity" in these discussions means simply "legal ability." Mr. Foote's attempt to distinguish incapacity from the results of an isolated prohibition (such as prevents marriage within the degrees of affinity, or, we suppose, of impotent persons) only introduces an unnecessary difficulty, though supported by dicta in Ogden v. Ogden [1908] I P. 46. If it is not legal for A to enter into a particular union, A has not "capacity" to make it. Wilson v. Cook (I9r3) 40 Clunet, 986.

' [rgo8] x P. 46.
} 
the peers who took part in the decision, Campbell, Cranworth, St. Leonards, were or had been Lord High Chancellor. Wensleydale (Baron Parke) was the most consummate common lawyer of his day. Not the decision alone but the language of the parties to that opinion indicated clearly that capacity to contract marriage is governed by the personal law of each party.

Marriage is a sort of co-emptio; and caveat emptor. Each party must beware lest the other may chance to be incapable. The fact of foreign connections will generally be patent. In any case, a deceived party is in no worse case than a party to a bigamous marriage. Some risks must be taken by anyone who embarks on matrimony. And one who marries a foreigner is put upon inquiry.

But "hard cases make bad law": and hard cases began to arise. Persons of foreign domicile came to England and induced English persons to go through the form of marriage with them in England. The anxiety of the judges ut res magis valeret led them to break holes in the clear doctrine of Brook v. Brook.

Let it be observed that the principle that capacity to marry is measured by the personal law, and not by the law of the place of celebration, is quite independent of any general theory of capacity to enter into contracts. Marriage is an affair, not of contract, but of status. It is not the promise to marry, but the ceremony of marriage, of which we are treating. Capacity to make ordinary business contracts and the casual agreements of everyday life may well be regulated by the law of the place of contract, or the place of its contemplated performance. The acceptance of a totally new status, affecting the entire future of the party, is quite a different matter. Let it be noted, too, that for American and English lawyers, the "personal" law is the law with which an individual is presumed to have most to do, and to be most in touch with-the law of his or her domicile, i. e., the last place where he or she was settled with no intention of ever permanently removing therefrom. On the continent of Europe (though not generally in South America), the criterion of the political nationality has, through political causes, for some halfcentury supplanted it, except in Denmark and Switzerland. And it will further be borne in mind that domicile in England means something very much more permanent than the continental domicile. It is almost impossible to acquire a new domicile in the English sense, except by very long residence or the closest connection. On the other hand, a Danish domicile determining 
his age of majority was held, in Copenhagen, to have been acquired by a Swede who had been three years a steward on Danish steamers. No intention to reside permanently in Denmark was shown, and this would have been imperative by English practice.

Now, it was admitted in Brook v. Brook that the ceremonial and forms of the marriage must be those of the country where it is celebrated. Lex loci regit actus. ${ }^{4}$ And therefore one means of evading Brook v. Brook was ready to hand. One could call an apparent incapacity a mere matter of form. In fact, Lord Campbell had suggested this, in Brook v. Brook itself. He explained an earlier case, Steele v. Bradzell, ${ }^{5}$ which he might have overruled or (as being an Irish case) disregarded, as one in which there was no real question of incapacity, but one of form merely. Certain consents, required by the law of the domicile, but not by the law of the place of celebration, were held to be no essential conditions of capacity; and a person who could not marry without them in his own domicile, Ireland, was held to be bound if he purported to marry without them in Scotland..$^{\prime}$ But on such reasoning one could explain away almost any incapacity as a matter of form, as Westlake observes. They were imperative restrictions, just as much as the attainment of a particular age. Another case, decided rather later than this, was perfectly in consonance with the doctrine of Brook v. Brook, but was difficult to reconcile with Campbell's explanation of Steele v. Bradwell. This was the Sussex Peerage Case. ${ }^{7}$ The Duke of Sussex had married Lady Augusta Murray at Rome without the consent of King George III. If consents were matters of form, the law of Rome knew nothing of the British Royal Marriage Act, and the marriage was perfectly good. The Lords decided otherwise, advised by the judges. It is diffcult, if not impossible, to reconcile these two cases; and it

This maxim is not accepted by all countries as excluding the validity of the forms prescribed by the personal law.

${ }^{5}\left(\mathrm{r} 83^{8}\right)$ I Milw. Eccl. I. This case was decided by Dr. Radcliffe, the Episcopal Chancellor of Dublin-if the writer's recollection is correctand would not of itself be of very great authority.

-Martin v. Foberg (1889) I6 Clunet, I38. Cf. Winans v. AttorneyGeneral [1904] A. C. 287 , where twenty years' residence was held insufficient.

${ }^{7}$ (I844) II Cl. \& F. 85. Distinguish Prince de Sayn's Case (1883) 10 Clunet, 3r2. 
seems best, with Westlake, to treat the Irish one as overruled, and to dissent from Lord Campbell's view of it. Consents, if imperatively required, are matters of capacity and not merely of form. Still, when they are not imperatively required, but can be evaded by the observance of further formalities-as by the acte respectueux in France-they can be plausibly, and perhaps rightly, represented as mere forms. And so, in Simonin $v$. Mallac, ${ }^{8}$ the divorce judge, Cresswell, succeeded in upholding the English marriage of a domiciled French subject who had not obtained the necessary parental consents-on the ground that by observing certain forms he might, even in France, have done without them. ${ }^{9}$

But the more insidious ground of attack on the broad principle of Brook v. Brook was the fact that both parties had there gone abroad to evade their common (English) personal law. That was not the ground of the decision, which was squarely placed on the propriety of recognizing the limitations imposed on each party by his or her personal law, irrespective of their desire to evade it. The Lords do not stress the special impropriety of two persons conspiring to avoid the operation of their joint personal law. And in a very remarkable case of Mette v. Mette, ${ }^{10}$ Cresswell laid down the same rule of the paramountcy of the personal law, where only one party was subject to the incapacity. A domiciled Englishman purported to marry his deceased wife's sister in Frankfort. Her law (German) did not prohibit the marriage: his did, ${ }^{11}$ and Cresswell held it invalid.

\footnotetext{
(1860) 2 Sw. \& Tr. 67.

- Olivecrona, Validité du mariage des étrangers devant la loi suédoise, (1883) 1o Clunet, 35I, 352, thinks that in Sweden consents would always be treated as matters of form.

${ }^{10}$ (1859) I Sw. \& Tr. 4I6; see also De Wilton v. Montefiore [1900] 2 Ch. $48 \mathrm{r}$.

II Foote, Priv. Int. Jurispr. (4th ed.) p. I00, suggests that the personal law of the intended husband, being that of the "intended matrimonial domicile," may be decisive. But this is surely preposterous. Until the marriage is celebrated the lady is properly still under the protection and scope of her own personal law. It lies with it to say whether her intention can be lawfully carried out; that is, if we adopt the doctrine of the personal law being at all decisive. In Mette v. Mette, supra, Cresswell says that there can be no contract unless each is severally competent to contract. And in fact, Foote himself, p. 97, recognizes that to apply to the lady the law of the other party's domicile is "to beg the question of their marriage."
} 
In this state of the decisions, it seems impossible to say that common elopement to evade a common incapacity was the true ground of Brook v. Brook. It was the intention of the House of Lords to lay down a general principle of the paramountcy of a personal law. The question arose, but unfortunately not for ten years, in Sottomayor v. De Barros. ${ }^{12}$ This case had a complicated history. It was first tried on the footing that both parties were domiciled Portuguese; and subsequently, in some manner not easy to understand or to explain, on the footing that one was, by domicile, Portuguese and the other English. The most authoritative judgment (that which was delivered by three Lord Justices on the appeal in the first case) completely confirmed Brook v. Brook in the fullest sense: indeed Lord Justice Cotton enunciated the authority of the personal law as applying to all contracts, and his opinion remains the principal authority for that proposition. Sir R. Phillimore, in the court below, had not applied the Portuguese personal law, distinguishing Brook $v$. Brook partly on the ground that the latter was a case of English people evading English law abroad, whereas this was only a case of foreigners evading foreign law in England; and partly on the authority of Simonin v. Mallac. The Court of Appeal reversed this, and expressly put the case on the broadest principle, apart from national considerations, and as expressly, adopted the view that Simonin v. Mallac turned on the purely formal character of the consents there required. But the Queen's Proctor intervened: the case was retried before the divorce judge Hannen on the footing that the asserted husband had been domiciled in England. Hannen seized at that circumstance to explain away Brook v. Brook on a ground which had not been argued before the Court of Appeal (and could not well have been), viz., that it applied only to cases of an elopement to evade the stringency of a common personal law. ${ }^{13}$ Such were certainly the facts in Brook v. Brook; but as we have seen, the case did not turn on this peculiarity. And Hannen's view was diametrically opposed to (I) the dicta of the Court of Appeal in the earlier case of Sottomayor $v . D e$ Barros; (2) the speeches of the Lords in Brook v. Brook; (3) Mette v. Mette. That is, it conflicts with Matte $v$. Mette, if mutatis mutandis, a foreign

${ }^{12}$ (1877) 2 P. D. 8I; (1878) 3 P. D. I; (1879) 5 P. D. 94

${ }^{13}$ Cf. Roth v. Roth (1882) ro4 Ill. 35; Wilson v. Cook (19r3) 40 Clunet, 986 . 
prohibition is as much entitled to be recognized as an English one, which one is tempted sometimes to believe the courts are slow to realize.

Nevertheless, when the question, having enjoyed a refreshing sleep of thirty years, came up again in Ogden v. Ogden, it was Hannen's views, and not St. Leonard's, Wensleydale's, Cotton's, Cresswell's or Campbell's, that had the most influence with the court. Here was a French boy, Léon Philip, incapable of marriage by the observance of any formality, without a certain consent. He came temporarily to England and married without it. ${ }^{14}$ The Court of Appeal, affirming Justice Deane, held him validly married. Apparently they regarded this indispensable consent as a "formality," and intended to leave the question open of the effect of an "absolute prohibition" imposed by the personal law. Confusion is thus worse confounded. The conjecture may be hazarded that in the future the doctrine of Brook

14 This, it will be seen, was precisely parallel to the case of Prince Jerome Bonaparte, who married Miss Patterson in Maryland at the age of nineteen, without the consents required by Napoleon I's then recent code. The validity of this marriage, Wharton says, has never been contested in the United States. Cf. his article, Du mariage aux ÉtatsUnis (1879) 6 JOUR. DE DROIT INT. PRIVÉ, 228, 235. It will be remembered that Napoleon I's own marriage to Josephine was annulled for reasons of form. Wharton's opinion that the Pope, in refusing to annul Jerome's marriage, adhered to the view that the personal law does not extend beyond the limits of the lawgiver's territory, appears to rest on a confusion. In the eyes of the Vatican, the edicts of the French lawgiver were not in issue. The only question for His Holiness was, had the decrees of the Council of Trent been promulgated at Baltimore? and it was found that they had not.

Military consents are needed in various cases. I doubt much whether they would be treated as imperative in England; not because they are mere formalities, but because they are on a par with monastic disabilities. But German disabilities of this kind have been enforced in Belgium. Bausch v. State (1914) 4I Clunet, 990.

Governmental consents are (or were) required in Bavaria (except the Palatinate) and the Tyrol, and in the former country entailed, until I892, nullity if pretermitted. In 1872 , this was relaxed in the case of Bavarians settled out of Europe; and in 1892, the penalty of nullity was retroactively relaxed, which produced some very pretty metaphysical problems as to bigamy. These were rendered the more easy of solution in that the invalid marriage could always be validated by an ex post facto certificate of consent. Keidel, Le mariage des Bavarois à l'étranger (I897) 24 Clunet, 986. In Greece the consent of the bishop of the diocese is requisite. (Ig03) 30 Clunet, 9ro. 
v. Brook will be reverted to, whether the parties have the same or different domiciles; and that possibly the anomalous exception of disregarding foreign incapacities to marry without certain consents will be maintained, and represented as justified by the formal character of such legislative provisions when enacted by another than an English legislature.

The personal law, even if admitted to be decisive, may be selflimiting. It has been held in Austria, that the prohibition of marriage between a Catholic and a Jew is directed merely against the scandal of celebration within the realm. Such a marriage elsewhere contracted by parties whose personal law is Austrian will, it was said, be regarded as valid, if valid where celebrated. ${ }^{15}$ But the same court, a year previously, had held invalid the marriage in Saxony of a Catholic Austrian with a divorced person (a Saxon $)^{18}$; and in 1904 had done the same in regard to this very case of Austrian Catholic and Jow marrying abroad. ${ }^{17}$ More than that, the same court had in IgO4 also laid down that such a mixed marriage was intolerable to Austrian law, wherever or by whatsoever country folk contracted ${ }^{18}$ The Irish case of Swift v. Attorney-General must, of course, be clearly distinguished from the first-mentioned of these Austrian cases: in Swift's case, the party could have married in Ireland itself, by the use of a proper form-the employment of a Protestant minister. The statute, I9 Geo. II, which prohibits Protestants from being married by a Catholic priest, does not impose on them any incapacity to marry Catholics. It merely regulates forms, and a domiciled Irish Catholic did not need to observe them abroad. It is not, therefore, the case of a self-limiting personal statute, as the Austrian law (as interpreted in the case referred to) might be. It may be noted that the present tendency in Austria appears to be to apply all these personal incapacities to Austrians who marry abroad, if (and only if) the marriage is intended

\footnotetext{
${ }^{15}$ (1908) 35 Clunet, 554, citing (1908) Zeitschr. für int. Privatrecht, 57x, and (1907) Juristische Blätter, 82; (1909) 36 Clunet, 818, citing (1905) Zentralblatt, 717; (I91I) 38 Clunet, 296, citing (1907) Zentralblatt, 142.

${ }^{26}$ (1908) 35 Clunet, 1217, citing (1906) Juristische Blätter, 50r ; see also, (1909) 36 Clunet, 536, II60, II64, I167, citing (I906) Zentralblatt für juristische Praxis, 1020, 654, 131, 128, (1905) 726.

${ }^{17}$ (Ig06) 33 Clunet, IIgo.

${ }^{18}$ On the other hand it was held in Germany that it was equally intolerable to German law to recognize such a religious incapacity. (Ig06) 33 Clunet, rigr (Austrian married in Germany). (Ig09) 36 Clunet, 785.
} 
(or perhaps calculated) at the time of its celebration to have legal results in Austria ${ }^{10}$ - a somewhat forced interpretation of section four of the Civil Code which seems to have been enacted alio intuitu, and not to deal with these questions of public policy. ${ }^{20}$ And the extreme doctrine, that a Catholic-Jew marriage is abhorrent, appears to have been abandoned in I904, when an American non-Christian and an American Catholic, resident in Austria, were held to have been validly married in the United - Kingdom, although they visited it for that express purpose.

II

FORM AND ESSENCE

Great difficulty has arisen from the fact that the notions of all countries are not all alike as to what is matter of capacity; of the essential nature of the contract of marriage; and what is matter of form.

In France, the Tridentine idea has long been current that "clandestinity" is something more than matter of form, and

${ }^{20}$ (Ig14) 4I Clunet, 244, 1325; (I910) 37 Clunet, 637; (I91r) 38 Clunet, 296. This doctrine seems to date from a decision of 1905. (1909) 36 Clunet, 8I8. It evidently gives rise to great difficulties of application. It approximates in practice to applying the law of the domicile (in the Anglo-American sense). In fact, the decision of the Vienna court in 1907, (I9II) 38 Clunet, 296, declared such mixed marriages between Austrians abroad to be valid "if at the time of the celebration, they entertained no intention of returning" to Austria: precisely the definition of domicile. Nevertheless, in 1909, a tolerably recent decision (I9Ir) $3^{8}$ Clunet, 299, citing (1910) Pravnik, No. xix, adheres to the doctrine that the prohibition is not local, and that the provisions of sec. 4 of the code cannot be relied upon to confer capacity abroad, since marriage is a life-long and world-wide institution "calculated" and "intended" to confer rights in all countries. To the writer this appears a much more juridical view. Other decisions upholding the doctrine of specific "intention" are in (I9II) 38 Clunet, 967, 1297. It is essentially the same judicial looseness as makes the British courts adopt, as the proper law of a contract, the law which the parties "intended" to choose, in spite of the fact that, as Westlake says, it is. the very lawfulness of that intention which may be in dispute. The uncertainties and difficulties of such a criterion are manifest. As to the doctrine of "intention" in prize law, the reader may consult the writer's Britain and Sea Law, passim.

${ }^{*}$ That sec. 4 is really not in point, is proved by the fact that, in applying it, the usual temperamenta are not applied, i. e., a minor's "intention" is given full effect to, although it certainly would not be regarded in a case of ordinary contract. (IgII) 38 Clunet, 969; (I9I4) 4 I Clunet, I325. 
that its absence, judged by French standards, constitutes, so to speak, part of the essence of marriage. But unless we regard the word "forms" as equivalent to "otiose forms," such an attitude is really one of revolt against the maxim locus regit actus. Forms are directed to securing some matter of substance: to say that the forms which one nation uses are not sufficient to guard against clandestinity, is to elevate one's own forms to the plane of essentials. The same may be said of the Servian view, according to which, as ably expounded by Prof. Péritch, marriage is a sacrament, and the ecclesiastical form of the Orthodox Church is an essential. That is, in effect, to relegate nonOrthodox marriages to a category having nothing in common with marriage, and to regard them precisely in the way in which English law regards Oriental marriage, namely, as a different juridical institution. These questions are not so much questions of capacity, as questions of the essentials of marriage. But they are so closely allied to matters of capacity that it is worth saying a word about them. The objection to "clandestinity" does not, in France, annul every marriage entered into by French people abroad without the necessary ratification in France and consents by French parents. But it is left to the judge to say whether they were dispensed with for the sake of clandestinity-an unsatisfactory position. ${ }^{21}$ The marriage of one Sarah Bernhardt with a Mr. Damele, a Greek, in England, without French forms of ratification, was upheld in $1888 ;^{22}$ but very many marriages of minors have been annulled in France and in Belgium, and some in Italy, for want of them. It seems to be otherwise in Holland.23 New York, in I9I2, annulled a marriage of domiciled New Yorkers in New Jersey, for want of parental consent, one party being eighteen ${ }^{24}$; but it is probable that in this case the marriage would equally have been invalid in New Jersey itself.

Still more difficulty attends the case, arising in Servia, Bulgaria, Greece, and Russia, where only religious marriages are

\footnotetext{
${ }^{21}$ In a recent Belgian case, Du Bois de Bianco v. Veuve du Val de Beaulieu (1913) 40 Clunet, 1322, a marriage was held not clandestine although one of the motives was to give it less éclat in the eyes of a relation.

${ }^{2}$ Ballande v. Bernhardt (I889) I6 Clunet, 641. A contract was repudiated, as made without marital concurrence.

${ }^{23}$ Reitz v. Dieten (I908) 35 Clunet, 1273.

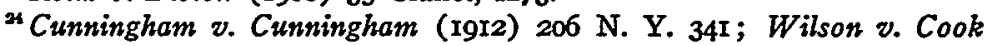
(Igr3) 40 Clunet, 986.
} 
recognized..$^{25}$ Is the religious ceremony a mere form? or is it part of the essence of the institution? According to the law of the countries in question, it is part of the essence, but that is not the point. What is it, from the standpoint of other nations? It is almost certain that the religious ceremony would be regarded as pure form in England or Scotland, whatever might be the case in Ireland and Quebec. Yet, in France, ${ }^{26}$ it was long regarded as a matter of capacity, to be regulated by the personal law. A Russian was held unable to marry in France, therefore, without a religious ceremony, according to decisions which have been severely criticised by $M$. Perroud and are contrary to a Belgian case of $1905 .{ }^{27}$ In I9I3, the French court definitely discarded them. ${ }^{28}$

Conversely, a purely religious marriage will be recognized in France, if it has taken place in accordance with the laws of the place of celebration, even though a religious marriage produces no legal consequences in France; at any rate, if subjects of that place are alone concerned. ${ }^{29}$

At first sight, the problem which we saw arose in Swift $v$. Attorney-General seems to be the same problem as this. But it is not really so; because in Swift $v$. Attorney-General nothing turned on the asserted sacramental character of the marriage. It was as pure a question of form as could well be imagined. These Servian and Russian cases, in which a non-sacramental marriage is not the same kind of marriage at all, involve totally different principles. Take a case like Stathatos $v$. Stathatos, ${ }^{30}$

\footnotetext{
${ }^{25}$ On the whole subject of sacramental marriages, see Péritch, De la compétente en Serbie ( 1900 ) 27 Clunet, sec. I, p. 742.

${ }^{25}$ Edinson v. Edinson (I908) 35 Clunet, II48.

z (1905) 32 Clunet, 1085, affirming Perlmann v. Bechhafer.

${ }^{28}$ (IgI4) $4 \mathrm{I}$ Clunet, 202, affirming Roitstein v. Roitstein. This case, however, proceeded less on the footing that religious ceremonies were matters of form than on the sweeping assumption that it was repugnant to French law to notice religious institutions. The logical consequence of this position would be to refuse recognition to all religious marriages wherever celebrated. See Durrighello; see also Mosliczker v. Mosliczker (I906) 33 Clunet, II46. Austrian Jew married in France without religious ceremony. Marriage was held void.

${ }^{20}$ (1916) 43 Clunet, 1606, affirming Durrighello.

${ }^{30}$ [19r3] P. 46; cf. Gachon v. Gachon (1894) 21 Clunet, r38. In this case the fact that consent could have been dispensed with by a formal procedure was treated, not as reducing the consent to matter of form, but as evidencing the absence of "clandestinity." Unlike Philip in Ogden v. Ogden, supra, Gachon was thirty years of age.
} 
where a Greek married Caroline Henry in England without the presence of an Orthodox priest; where the parties actually lived together for some time; and where the Greek courts ${ }^{31}$ rendered eventually a nullity decree, because the sacramental union had not been created, which alone they considered a domiciled Orthodox Greek competent to enter into. The marriage was clearly good in England, and it was only by stretching a point and assuming jurisdiction where there was no domicile that the English court granted a dissolution decree. ${ }^{32}$

\section{III .}

BARS UNKNOWN TO THE PERSONAI LAW

The question does not seem ever to have been much discussed in England of whether the personal law can override the local law, so as to make a marriage good, as well as to make it bad. Can a person who is of age in her own country marry when she is temporarily abroad in a country where the age of consent is above her own? Will the English court recognize the capacity of a foreign domiciled uncle and niece to. marry in England, if such a union is permitted by their personal law? Will it recognize as valid the marriage of domiciled English

st The English courts will probably not entertain an action of nullity unless the defendant is domiciled, or at least resident, in England. In Linke v. Van Aerde (1893) Io Times L. R. 426, the fact of England being the locus celebrationis was held sufficient. But if the question of marriage or no marriage arises indirectly, they will not hesitate to decide it on proper evidence of the law of the foreign country, or countries, which may be concerned. Spain equally abstains from deciding directly on the marriage even of Spaniards in a foreign country and in foreign forms. $P$. y B. José v. G. Isabelle (I912) 39 Clunet, 284. But Brazil is so accommodating as to give divorces on German grounds to German subjects in Brazil although its own law recognizes no such thing as divorce, Ulbrich v. Ulbrich (I913) 40 Clunet, I329; and France, with even greater complaisance, hands it over to French Jews to divorce Russian Jews in France, Rosenbaum v. Kuhn (rgI2) 39 Clunet, I92.

${ }^{22}$ For the reasons above given, p. 452 f., I think it a mistake to do this. There is no natural right to divorce, which must viis et modis be subserved. And it is somewhat grotesque to treat a man as living in adultery because he is living with a person who by the law of his domicile (which is what English law recognizes as determining his status) and nationality is his lawful wife. To mix up the laws of two or more countries in order to ascertain a person's marital position is a risky adventure. 
cousins in Portugal, where the local law forbids such marriages? It is possible that different answers will be given to these questions just as different answers were given to the inverse problems raised in Mette v. Mette and Sottomayor v. De Barros, two consistorial cases, on which Mr. Westlake relied to show that the local law must be complied with, which are very inconclusive. ${ }^{33}$ The Hague Private Law Conventions, ${ }^{34}$ which Mr. A. K. Kuhn has so well put before English readers in his edition of the late Professor Meili's work, allow a country to refuse validity to marriages celebrated on its soil which outrage its religious provisions. But even these Conventions do not entitle a country to refuse validity to marriages which violate the religious prohibitions of other places of celebration. Thus, if we regard a marriage between uncle and niece as prohibited in England on religious grounds, which it undoubtedly was at the inception of the prohibition, England would, nevertheless, be obliged to recognize such marriages, valid by the Norwegian personal law of the parties, if they were celebrated in New York, even though New York law might, on equally religious grounds, contain a similar prohibition-a sufficiently absurd result. Moreover, it is difficult to assign a positively religious basis to most prohibitions: probably the special obligations of monks and nuns were alone in view when the Convention was framed. Thus the word "religious" would have a very narrow interpretation. It seems altogether too ambiguous a term to be employed in so important a context. The Belgian court has declined to regard the prohibition to Catholics to marry divorced Catholics as based on religious grounds. ${ }^{35}$

It is perhaps not unnatural that one, always ready for adoption, should turn with a certain sense of relief to the alternative of discarding the personal law in all these matters of capacity, and of leaving the decision entirely to the local law, and this is

\footnotetext{
"Scrimshire v. Scrimshire (1752) 2 Hagg. Cons. 395; Middleton v. Janverin (1802) 2 Hagg. Cons. 437. In both cases the local forms had not been complied with; nor can Simpson and Wynne who decided them be looked upon as first rate authorities.

"Neither the United States nor the United Kingdom is a party to these instruments, the effect of war on which is the subject of argument. Pillet seems to hold, with justice, that such multiple conventions are in principle destroyed by the outbreak of war between any of the parties; though the rest may tacitly resume the pact.

${ }^{2}$ Ritter v. Miko (I904) 3I Clunet, I342.
} 
the view put forward by the late Chief Justice of England in an article written in 1897.36 There is no reason why a foreigner should not make himself acquainted with that law's provisions when taking so important and irrevocable a step. There is no likelihood that anybody will be deceived as to what country he is being married in. The evils of a conflict between the lex loci celebrationis and the lex civitatis are apt to be much exaggerated. They may be avoided by ordinary care; and it may be better to have one's marriage valid in one's own country alone, than to be obliged to find oneself unmarried anywhere. Possibly a better solution might be to allow a marriage to be good which is valid according to any law which may reasonably be invoked as applicable-lex loci, lex domicilii, lex civitatis ligeantiae, perhaps lex fori. But the world of IgI7 A. D. is by no means ripe for such a development. ${ }^{37}$ The worst solution of all, however, is that of enforcing one's own law as a personal law abroad, while refusing, or grudgingly according recognition to foreign laws at home. Ogden v. Ogden marks a strong tendency to protect English ladies of mature years from the consequences of their own imprudence, and to do so at the expense of foreign minors. It is almost to be regretted that the case did not go to the House of Lords, which tribunal could scarcely have failed to remark the difficulty of distinguishing between an incapacity to marry without parental consent and any other substantial incapacity. It is remarkable that the Italian law, which is almost as devoted as Mr. Weiss to the supremacy of the law of the nationality over the personal status, declines to hold a foreigner entitled to marry in Italy if he is a minor by Italian law!

And it must always bo remembered that no country will enforce a union, whether contracted within or without its limits, and whether between its domiciled inhabitants or anyone else, which is repugnant to its criminal law or to its sense of morality. Thus, we cannot expect that a union between niece and uncle would be recognized in England in the case (which Olivecrona ${ }^{38}$ assures us has occurred) where the persons were Norwegians living in Norway at the time of their marriage, although the marriage may have been perfectly valid there. Yet some effect might

${ }^{28}$ (I897) 24 Clunet, 669. This rule is said to be adopted in the United States, in Argentine, and in Brazil.

${ }^{87}$ Cf. Jitta, Obligations, passim.

${ }^{88}$ Le mariage des étrangers en Suède (I883) Io Clunet, 352; (IgII) 38 Clunet, 402. 
be allowed to its operation on property situate in England on the footing of its being a contractual arrangement with the morality or criminality of which the English courts had nothing to do.

In Sweden, the repugnance to such a marriage, though it would be invalid in Sweden, would apparently not extend to induce the Swedish courts to treat it as invalid under such circumstances unless the husband acquired Swedish nationality, though it still remains forcible enough to induce Sweden to take advantage of the liberty accorded by the Hague Private Law Convention, to refuse such relatives permission to marry in Sweden. ${ }^{39}$

In Switzerland, it appears, such marriages are illegal, but if contracted abroad, will be accorded recognition ${ }^{40}$ even when the parties are Swiss and domiciled in Switzerland. Switzerland appears only to marry such foreigners as are domiciled (permanently settled) in Switzerland. ${ }^{41}$ This is not a bad solution of the whole difficulty for those countries whith adopt domicile as the criterion of the personal status. Why should a transient foreigner wish to marry? Why should not his intended consort establish a domicile in the country where such a stranger is settled? There are answers to these questions, but apparently Switzerland regards them as insufficient.

In England a marriage between a widow and the brother of her deceased husband, celebrated in Italy between domiciled ${ }^{42}$ Italians, was naturally held valid. ${ }^{43}$ Naturally, because such marriages caused no repugnance to public sentiment-the House of Commons had repeatedly pronounced in favor of very similar ones-so that there was nothing to prevent the Italian law from applying, as the law of place and domicile combined. But in Guernsey, the Dean annulled the marriage, there celebrated, of a divorced person though domiciled and divorced in England. ${ }^{44}$

We, therefore, need clearly to distinguish those cases in which capacity is a mere matter of local regulation, and those in which

\footnotetext{
* Reuterskiöld, Le mariage, le divorce et la tutelle d'après le droit international privé suédois (I9Ir) 38 Clunet, 405.

${ }^{20} \mathrm{~A}$. Martin, Du mariage et du divorce des étrangers en Suisse (I897) 24 Clunet, 740, 747; but cf. 922.

A. Martin (I897) 24 Clunet, 740.

12 It is worth noticing that the lady was of British nationality.

is In Bozzelli [1902] I Ch. 75r.

"Smith v. Kentfield (1889) I6 Clunet, I30; (Dec. 6, I888) London tIMEs.
} 
it rests on an energetic sentiment of repulsion. In the former case, it is possible that the personal law will prevail over local bars (at any rate, when it is also the lex fori). In the latter, it cannot often prevail over the bars established by the lex fori, and whether it prevails over the bars of the lex loci is a very dubious question. Suppose the question to arise in an English court of a marriage per verba de praesenti of black and white persons in an American state where such marriages are prohibited, both parties being domiciled in a state where they are permitted. The lex fori, entertaining no sentiments of repugnance to such a union, has no reason for disregarding the capacity conferred by the lex domicilii. Will it take account of the repugnance of the lex loci? It is probably not repugnant to its own ideas to do so; to recognize such prohibitory legislation is not like recognizing religious vows or slavery ${ }^{45}$ or penal law. But will it think it necessary to draw the line between prohibitions that are specially dear to the lex loci, and prohibitions that are not so deeply rooted in its sentiment? Will it allow marriage with a deceased husband's brother to be valid, and treat marriage with a negro as void, where both are prohibited in the locus and permitted in the domicile? It is impossible for a foreign court to draw any such line. If it recognizes the capacity conferred by the personal law as overriding the law of the locus, it must recognize it for all purposes, saving its own overpowering predilections. ${ }^{48}$ The difficulty of attempting to draw such a line, even for itself, is considerable. Thus, Busdugan ${ }^{47}$ does not think that a Roumanian court would decline to recognize the marriage of a twelve-year-old Austrian in Roumania, whilst it would so decline to recognize the marriage of cousins, or of a deceased wife's sister.

We have seen the Supreme Court of Austria varying, within two short years, in its manner of regarding Jew-Christian marriages: at one time finding no fault with them, so long as they

\footnotetext{
45 It illustrates the difficulty of the whole subject that Busdugan, infra, thinks that the Roumanian tribunals would have no repugnance to recognizing religious bars whilst they would refuse to recognize bars based on color or race distinctions. $\mathrm{He}$ is speaking of marriages solemnized in Roumania between strangers.

"Saving also the operation of a renvoi by the personal law, for those who accept the guidance of this will o' wisp doctrine.

"See an exhaustive and able article, Du mariage des Roumains à l'étranger (Ig00) 27 Clunet, 749, 757.
} 
are not solemnized in the sacred dominions; at another, regarding them as impossible for an Austrian subject; at another, declining to recognize them at all, as being fundamentally inconsistent with Austrian ideas. This shows how impossible it is for unfortunate private persons or for the courts of other countries to draw the delicate distinction. It may be added that the Supreme Court at Vienna usually contradicted the courts below.

Parenthetically, these fluctuations of opinion show how impossible is the contention of Mr. Weiss, that the Tables of Affinity must invariably be matter d'orde public, which a nation can never relax in favor of foreign regulations. Whilst England was counting among its prohibited affinities that which exists with a deceased wife's sister, it was actually passing a statute declaring that marriages within that prohibited degree contracted (even in England) by persons domiciled in the colonies where such unions were lawful, were valid to all intents in England. The violation of orde public then, implies a real horror or shock to the national juridical consciousness, which is by no means found in all the exceptions to the currency of foreign "personal" law in a given country.

\section{IV}

\section{MARRIAGE AND KINDRED INSTITUTIONS}

It must always be remembered that when we are discussing the legal requisites of marriage, we mean marriage, and not the miscellaneous unions which are loosely and in a literary sense termed such. No polygamous union is regarded as marriage. ${ }^{48}$ This provides the simple key to various cases which have been the occasion of considerable perplexity in England. Thus in Chetti v. Chetti, ${ }^{49}$ there was a case of a Brâmin; in Re MirAnwaruddin, there was the case of a Mohammedan, affecting to marry an English person in London. Each subsequently attempted to avail himself of the incidents and provisions of the law of his domicile (India). The fallacy was to assume that these incidents had any relation to an occidental marriage. A Brâmin can only contract a Hindû "marriage" with the members of certain specified castes. But neither Chetti nor his inamorata had any idea when they visited the registrar of a

is In re Bethell (I888) 38 Ch. D. 220.

[1909] P. 67. 
London marriage district, that they were contracting any such splendid and sacred union. They were celebrating-or at any rate trying to celebrate-something very different. And if $\mathrm{Mr}$. Chetti should urge that his personal law imposed on him an incapacity to enter into any such alien relationship as unsuited to a Brâmin, the answer is that, of penal and religious incapacities imposed abroad, the law of England takes no notice. Also such a prohibition could, in particular, be in restraint of marriage. So with regard to Mr. Anwaruddin's tangle. He married in England, but failing to induce his wife to live with him in India, he applied to the courts of his Indian domicile for a divorce. He not being a "Christian," they had no power under the statutes to grant relief. The proper conclusion would seem to be that he had no remedy-except possibly that of judicial separation in the ecclesiastical court of the Indian bishop. ${ }^{50}$ But, under the conviction that he must be able to secure a dissolution viis et modis, he purported to effect a divorce, modo islamitico, by a triple bill under his hand. Now, this might have dissolved a Mohammedan "marriage"; but he had not, by the ceremony in England, contracted a Mohammedan marriage-but something very different. He applied afterwards for the issue of a civil marriage license in London, on the footing of the former union being thus dissolved. The registrar refused to issue one, and the court of King's Bench declined to order that officer to do so. ${ }^{51}$ Dr. Anwaruddin had meanwhile obtained some encouragement from Justice Deane, who had expressed an opinion that the marriage was dissolved, in declining to entertain formal application by Dr. Anwaruddin for restitution of conjugal rights which proceeded on the footing that it still existed. The King's Bench, therefore, holds that Dr. Anwaruddin is married, and the matrimonial judge that he is not. The Court of Appeal may solve the conflict.52

\footnotetext{
${ }^{80}$ The power to grant matrimonial relief is incident to the bishops by common law. They have been deprived of it in England by statute. But if no other matrimonial jurisdiction exists-as apparently in India, where one party is not a Christian-it would seem to be unimpaired.

"A similar result was reached in French Tunis in 1908. Mignet $v$. Abdelaziz Sfar (1909) 36 Clunet, 1075. Cf. however, Achouche v. Touaty (1910) 37 Clunet, 56r, 564, where a Jew of Algiers who married a lady called Valensi before the French registrar, in 1863 , was held entitled to contract a subsequent Jewish marriage.

${ }^{82}$ [In Ex parte Mir-Anwaruddin (Igi6) II5 L. T. (Ct. of App.) 882 (issue of Feb. I7, I9I7) it was held that his marriage was, according to English law, still subsisting.-ED.]
} 
There remained possible alternatives for Mr. Anwaruddin, short of the heroic remedy of cutting the Gordian knot by a change of domicile or a bill in Parliament. English courts will only dissolve marriages where the husband's domicile is English. But there is beginning to be recognized an exception to that rule in cases where, for one reason or another, there is no possibility of procuring a dissolution in the foreign jurisdiction. It is not probable that jurisdiction would be assumed merely because divorce $a$ vinculo was unknown to the foreign law (as in Italy). If an English person chooses to marry an Italian, she must accept the consequences-including the indissolubility of the tie. But sometimes, where divorce is freely recognized, there is a hitch in the machinery. The most glaring case appeared from Ogden v. Ogden, where the English wife could not get a divorce in the French husband's domicile, because the French courts did not consider her married. It was suggested that in these circumstances the English court, though not the court of the domicile, might assume jurisdiction. And so it did in the subsequent case of Stathatos $v$. Stathatos, ${ }^{53}$ in which the domicile of the husband was Greek. As has been observed, the consequence is to introduce a new and serious confusion into marriage law. For the English court, thus assuming jurisdiction, can hardly apply ${ }^{54}$ any other than its own matrimonial law to the conduct of the parties and to the incidents of the divorce, which nevertheless if the foreign court had assumed the jurisdiction would clearly have been governed by the foreign law. There is a tendency to extend this assumption of jurisdiction to the case of a deserted wife. The American principle, according to which a wife may have an independent domicile, would thus be approximated to. But, so far this recognition of the right of the English court to entertain such a suit has been limited to the minor case of jurisdiction in suits for divorce a mensa et thoro, ${ }^{55}$ as to which it was long uncertain whether the true ground of assuming jurisdiction was domicile or mere residence. ${ }^{56}$ Still the doctrine might have been extended to relieve a Mohammedan Indian, who had contracted

\footnotetext{
[19r3] P. 46.

st And in fact, being the creature of precise statutory provisions, has probably no power to apply.

${ }^{s}$ Armytage v. Armytage [1898] P. I78.

${ }^{\infty}$ Nigoyet v. Nigoyet (1878) 4 P. D. I; Le Mesurier v. Le Mesurier [I895] A. C. 517 .
} 
a marriage, to deal with which there existed in his own domicile no machinery at all. It would be a dangerous principle, because non constat that the intention of the Indian legislature was not to deprive parties to such a mixed marriage of marital relief. But, being so seductive a principle, there is little doubt but that it would have prevailed, though the consequence is almost to consecrate Chev. Fortunato's doctrine that there is a "natural right" to divorce. ${ }^{57}$

Is it bigamy for an Oriental who has contracted an occidental marriage to contract a fresh one? Obviously so, if we are right: his liberty to have four "wives" has nothing to do with wives in the occidental sense. His oriental marriages, on the other hand, ${ }^{58}$ even if contracted in England or America, will not be bigamous because he already has "wives." They are an entirely different style of thing. Thus, it is said that an ex-inmate of Ismail Pasha's harem was duly admitted to marry an Italian at Naples. ${ }^{59}$ How far these positions are supported by American cases, particularly from Utah, the writer is not aware. Again, is intercourse with such "wives" adultery? Here we are on extremely difficult ground. But on principle, it seems to be so. It is true that the connection is not obnoxious to the penal law: the connection is a licit and a respectable one. But the foundation of the matrimonial law regulating the occidental marriage is religious and ecclesiastical. Although its connection with religion may have disappeared, so far as ceremonies and courts are concerned, it remains true that the principles governing it are the old ecclesiastical principles. For the sake of certainty they must be upheld unless and until they are expressly altered by the legislature. And the very core of the marriage relation, according to those principles, is its unity. Intercourse, however legitimate, with a second consort, is necessarily a ground of divorce $a$ mensa. And since the legislature has made it a ground of divorce $a$ vinculo, it seems a necessary consequence that its

"See Madrid Conference Report, International Law Association (rg13) p. 446 .

${ }^{48}$ Cf. Achouche v. Touaty (19ro) 37 Clunet, 56r, where a Jew of Algiers in 1863 married one Valensi before the French civil officer and was held probably entitled to marry in the Jewish form in her lifetime. In France, and on the continent of Europe generally, the distinction between monogamous marriage and the various forms of polygamy has never been distinctly perceived.

${ }^{\circ}$ (I889) I6 Clunet, 708. 
legitimacy and respectability will not hinder it from having this effect. It is not what the consort was entitled to expect.

On the other hand, the subsistence of an oriental marriage would seem to be no bar to the conclusion of an occidental one. It would, however, afford a strong ground for declining to accord the occidental consort a divorce founded on the continuance of relations with the oriental parties (unless such consort had been kept in ignorance of their existence), under the English system, which makes connivance or conduct conducing to the illicit intercourse, a ground for refusing relief.

In some countries, the ambiguity is solved by prohibiting marriage between Christians and non-Christians. The prohibition usually extends to Catholic and orthodox Christians only, and not to Protestants. On the other hand, it extends to Jews as well as Mohammedans and Hindûs. Such prohibitions would clearly receive no recognition in England, whatever the nationality or domicile of the parties, or (perhaps) the place of celebration. It is a cardinal principle that religious disabilities will not be noticed. As to the contention which is sometimes raised, that the Jewish religious law should always and everywhere be applied to Jews, neither the French ${ }^{60}$ nor the English law recognizes any such rule.

Thomas Baty.

INNER TEMPLE, LONDON.

${ }^{\infty}$ Gottlieb v. Gottlieb (Ig08) 35 Clunet, 813. In this curious case, the Seine Civil Court declined to allow a lady to impeach her marriage on the ground of a supposed incapacity on the part of the other consort (a Russian) to contract a civil marriage. But why not? The court styled the incapacity a "benefit" conferred on the Russian by his personal lawbut surely it was not solely as a benefit to him that Russia established it! 